\title{
A CONSOLIDAÇÃO DO E-COMERCE: UMA VISÃO POSITIVA EM MEIO AO CAOS
}

\author{
Luizi Agassi Benedet \\ Eliana Marcon Cadorin
}

DOI: http://dx.doi.org/10.18616/intcov10

A pandemia de coronavírus configurou-se como uma oportunidade de reeducação no que diz respeito à saúde e à higiene, já que fazer uma limpeza adequada das mãos usando água e sabão é o principal cuidado para evitar a contaminação. Para conter ainda mais a disseminação, do vírus a Organização Mundial da Saúde (OMS) recomendou o isolamento social. Nesse sentido, as empresas frente à crise econômica, puderam se beneficiar por meio do comércio eletrônico para continuarem operando desde que se reinventassem para o mundo digital, possuindo uma oportunidade de consolidar-se nesse meio até mesmo depois do término da pandemia.

Muitos empreendimentos que estudavam a estratégia de tornarem-se e-commerce, frente à pandemia, anteciparam sua entrada nesse setor, por acreditarem que essa mudança fosse uma das melhores formas de continuarem no mercado. Isso se deve ao fato de que muitas cidades impediram a livre circulação de pessoas, tornando a única alternativa o uso de internet para compras. Porém os empreendedores encontram dificuldades pelo caminho que devem ser enfrentadas com ações direcionadas para a transição; entre elas, investir em mídias, conquistar novos consumidores e adequar seu marketing e suas propagandas ao meio digital com o foco na melhor experiência possível a seu usuário.

Além disso, o número de sites destinados à compra aumentou significativamente e consequentemente acirrou a concorrência, tornando-se vital que a empresa proporcione a mais atrativa e otimizada experiência de compra.

Nesse contexto, as expectativas da Associação Brasileira de Comércio Eletrônico (ABComm), de que o e-commerce nunca deixaria de crescer mesmo com retração do Produto Interno Bruto (PIB) e/ou outras dificuldades, 
foram confirmadas, já que a entidade calcula a abertura de 80 mil novas lojas on-line durante a quarentena. Destacando ainda que subiu em quase um milhão o número de consumidores que haviam, pelo menos, efetuado uma nessa modalidade.

Diante do exposto, é observável a importância de alavancar os negócios no meio digital investindo de forma pesada no público que antes era resistente a tal modalidade de compra, devido à quebra de paradigma imposto pelo isolamento social. Um grande empecilho para esse modelo de compra está relacionado à falta de contato com o produto, à dificuldade de devolução e à demora na entrega. Para amenizar esse problema, deve haver maior disponibilidade de fotos, busca por alternativas de entrega mais baratas e rápidas, além de disponibilizar meios de comunicação e realizar o atendimento mais eficiente e rápido possível. Todas essas alternativas para melhorar a qualidade visam fidelizar os clientes de modo que realizem outras compras.

As mudanças ocorridas no $e$-commerce, neste momento excepcional, alavancam o já emergente mercado digital. Esse isolamento social proporcionou espaço para que as pessoas se reinventassem, priorizando mais a saúde. Nesse sentido, as empresas precisam caminhar junto a essas mudanças e impulsionar suas economia de maneira criativa para vencer a crise. E para tal se faz necessário trabalho estratégico, captação de clientes e enfrentamento da competitividade. A longo prazo, a loja física precisará se readaptar para estar intimamente ligada ao mundo digital, o qual não possui fronteiras, com vistas a auferir melhores receitas. Com tudo isso, prevalece a lei de sobrevivência darwiniana, já que quem melhor conseguir se adaptar é quem sairá consolidado. 